\section{Larger Pits Aid Reseeding of Semidesert Rangeland ${ }^{1}$}

\section{ROBERT D. SLAYBACK AND DWIGHT R. CABLE}

Manager, Plant Materials Center, Soil Conservation Service, USDA, Tucson, Arizona; and Range Scientist, Rocky Mountain Forest and Range Experiment Station, ${ }^{2}$ Tucson.

\section{Highlight}

Broad, shallow intermediate pits have proved to be longer lasting than conventional pits on semidesert range in the 6- to 8-inch summer rainfall zone in southern Arizona. Rainfall penctration avcraged twice as deep in the pits as on adjacent flats. Herbage production of buffelgrass averaged $2 \frac{1}{2}$ times as high, over a 4-year period, on the intermediate pits as on conventional pits, and five times as much as on similar adjacent untreated range.

Buffelgrass (Cenchrus ciliaris), in 1967, produced over five times as much herbage on a semidesert area pitted with a recently developed intermediate pit as on an adjacent area with conventional pits, and nearly nine times as much as similar untreated range. These results were obtained in a cooperative study by the Soil Conservation Service Plant Materials Center, University of Arizona, and the Forest Service on the Santa Rita Experimental Range, about 25 miles south of Tucson, Arizona.

Although conventional pits have often given good initial establishment of seeded grasses, they usually lose much of their effectivencss in retaining and storing water after the first year or two. Their reduced effectiveness is due largely to rapid filling of the pits with soil following typical torrential summer storms, and to excessive competi-

\footnotetext{
${ }^{1}$ Received August 20, 1969; accepted for publication October 21, 1969 .

${ }^{2}$ Central headquarters maintained in cooperation with Colorado State University at Fort Collins. Author stationed at Tucson, Arizona, in cooperation with the University of Arizona.
}

tion from native annual grasses and forbs. To overcome these problems, a modified bulldozer blade was developed jointly by the University of Arizona and Soil Conservation Service (Frost and Hamilton, 1964) to construct broad, shallow pits that serve the dual purposes of scraping away the annual grass and forb seeds and of providing longlasting basins (Fig. 1). These pits have been designatcd "intermediatc" pits. The pits are so arranged that all surface runoff water must go into or through the pits.

In this study, the conventional method of pitting was compared to the intermediate pits to evaluate their relative effectiveness in establishing buffelgrass, an introduced perennial grass from India that appears to be well adapted to this part of the southwestern semidesert. The conventional method of pitting has previously been reported as pitting or interrupted contour furrows (Anderson, et al., 1957; Anderson and Swanson, 1949). This report summarizes buffelgrass yields from 1964 to 1967 on areas planted in 1963, 1964, and 1965, and moisture penetration measured in 1963.

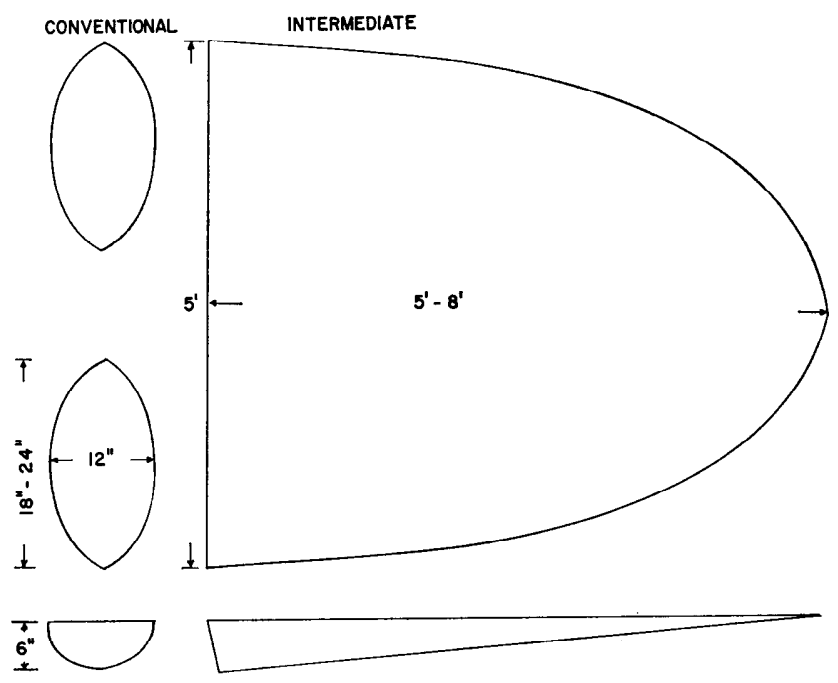

FIG. 1. Comparison of dimensions of conventional and intermediate pits. 


\section{Area and Methods}

The first of these annual plantings was made in May 1963 on the Santa Rita. The 29-acre study area is at about 3,000 feet elevation in Major Land Resource Area 40 (central Arizona basin range, Morris, 1965). The soils in the study area include slowly permeable clay loams, highly erosive sandy loams, and intermediate soils (Tubac, Sonoita, and Anthony series); replicate plots were installed on each of three soil types. The native vegetation included mainly velvet mesquite (Prosopis juliflora var. velutina), cholla cactus (Opuntia spp.), burroweed (Aplopappus tenuisectus), catclaw (Acacia greggii), six-weeks grama (Bouteloua bar$b a t a)$, and needle grama ( $B$. aristidoides).

Prior to planting, the mesquite was killed with diesel oil and the area fenced to exclude livestock. Jackrabbits and other rodents used the area heavily, however. Harvester ants were controlled prior to each planting. In each of the 3 years 1963, 1964, and 1965, two plots 400 to $600 \mathrm{ft}$ long and 2 or 3 pit-rows wide were established on the contour on each of the 3 soil types. One plot of each pair was pitted with a standard pitting disc and the other with the basining machine. The plots were then seeded to buffelgrass at about $1 \mathrm{lb} / \mathrm{acre}$ with a cultipacker seeder (1963 plantings were drilled as a part of the basining operation). The buffelgrass seed was purchased commercially and appeared to be the T-4464 strain of Texas origin. The intermediate pits were 6 inches deep at the lowest point (downhill side), 5 to $8 \mathrm{ft}$ long, and about $5 \mathrm{ft}$ wide. The conventional pits were about 18 inchcs long, 12 inches wide, and 6 inches deep.

One square $9.6 \mathrm{ft}^{2}$ quadrat was clipped in each of 10 pits in each plot annually in November after the season's growth was finished to sample production in the pits (systematic sample). Summer rainfall was measured on the site with a recording rain gage. Moisture penetration was measured with a soil probe evcry 7 to 10 days during the first summer, 1963.

\section{Results and Discussion}

Summer rainfall (July through September) for the 3 planting years varied widely (Table 1). The long-time average for the summer in this area is about 6.70 inches. Thus, 1963 was about $18 \%$
Table 1. July, August, and September rainfall (inches) at Santa Rita Field Evaluation Planting.

\begin{tabular}{lrrrrr}
\hline \hline \multicolumn{1}{c}{ Month } & 1963 & 1964 & 1965 & 1966 & 1967 \\
\hline July & 4.06 & 5.95 & 1.60 & 2.43 & 3.53 \\
August & 1.94 & 1.95 & 1.55 & 3.18 & 2.34 \\
September & 1.94 & 3.45 & 2.08 & 1.06 & .86 \\
Total & 7.94 & 11.35 & 5.23 & 6.67 & 6.73 \\
\hline
\end{tabular}

above; 1964, 69\% above; and 1965, 22\% below the long-time average.

Initial establishment of buffelgrass was strongly affected by the amount of rainfall in the year of planting, and this effect usually carried over to the following year. Thus, in 1964, the wet year, initial establishment was particularly good and the plots planted that year produced unusually well (194 to $990 \mathrm{lb} /$ acre, Table 2). In 1965, the dry year, initial establishment was poor, and production on plots planted that year was too low to warrant measuring (even in 1966, five of the six plots planted in 1965 produced less than $100 \mathrm{lb} /$ acre). However, this restriction in production, due to low rainfall in the year of planting, was only temporary; by 1967, the 1965 plantings were producing about as much buffelgrass as were the areas planted in 1963 and 1964 (except on the clay loam soil). Data for $1965 \mathrm{em}-$ phasize the importance of pits, and particularly of the intermediate pits, because production on the plots planted in 1963 and 1964 was about as high in 1965 as in 1966 and 1967 , even though 1965 was a dry year.

The data in Table 2 also show that, for the 1963 and 1964 plantings, initial establishment of buffelgrass was better in the conventional pits than in the intermediate pits. However, production on the conventionally pitted plots generally declined after the second year because of decreasing capacity of the pits to hold water. The intermediate pits re-

Table 2. Summary of yields (lb/acre) of buffelgrass in conventional and intermediate pits at the Santa Rita Evaluation Planting.

\begin{tabular}{|c|c|c|c|c|c|c|c|c|c|c|c|}
\hline \multirow[b]{2}{*}{$\begin{array}{l}\text { Soil } \\
\text { type }\end{array}$} & \multirow[b]{2}{*}{$\begin{array}{c}\text { Year } \\
\text { planted }\end{array}$} & \multicolumn{2}{|c|}{1964} & \multicolumn{2}{|c|}{1965} & \multicolumn{2}{|c|}{1966} & \multicolumn{2}{|c|}{1967} & \multicolumn{2}{|c|}{ Average } \\
\hline & & $\begin{array}{l}\text { Conv. } \\
\text { pits }\end{array}$ & $\begin{array}{l}\text { Int. } \\
\text { pits }\end{array}$ & $\begin{array}{l}\text { Conv. } \\
\text { pits }\end{array}$ & $\begin{array}{l}\text { Int. } \\
\text { pits }\end{array}$ & $\begin{array}{l}\text { Conv. } \\
\text { pits }\end{array}$ & $\begin{array}{l}\text { Int. } \\
\text { pits }\end{array}$ & $\begin{array}{l}\text { Conv. } \\
\text { pits }\end{array}$ & $\begin{array}{l}\text { Int. } \\
\text { pits }\end{array}$ & $\begin{array}{l}\text { Conv. } \\
\text { pits }\end{array}$ & $\begin{array}{l}\text { Int. } \\
\text { pits }\end{array}$ \\
\hline \multirow[t]{3}{*}{ Sandy loam } & 1963 & 238 & 105 & 933 & 1100 & 1540 & 1063 & 880 & 1590 & 898 & 965 \\
\hline & 1964 & 294 & 253 & 34 & 475 & 30 & 593 & 483 & 2310 & 210 & 908 \\
\hline & 1965 & & & & & 22 & 244 & 36 & 1590 & 29 & 917 \\
\hline \multirow[t]{3}{*}{ Loam } & 1963 & 0 & 612 & 143 & 870 & 5 & 503 & 93 & 568 & 60 & 638 \\
\hline & 1964 & 410 & 194 & 193 & 693 & 31 & 146 & 80 & 483 & 179 & 379 \\
\hline & 1965 & & & & & 37 & 83 & 103 & 1704 & 70 & 894 \\
\hline \multirow{3}{*}{$\begin{array}{l}\text { Eroded } \\
\text { clay loam }\end{array}$} & 1963 & 198 & 168 & 154 & 257 & 52 & 198 & 102 & 264 & 102 & 222 \\
\hline & 1964 & 990 & 274 & 1230 & 1830 & 206 & 700 & 199 & 2102 & 656 & 1227 \\
\hline & 1965 & & & & & 50 & 31 & 99 & 94 & 75 & 63 \\
\hline
\end{tabular}



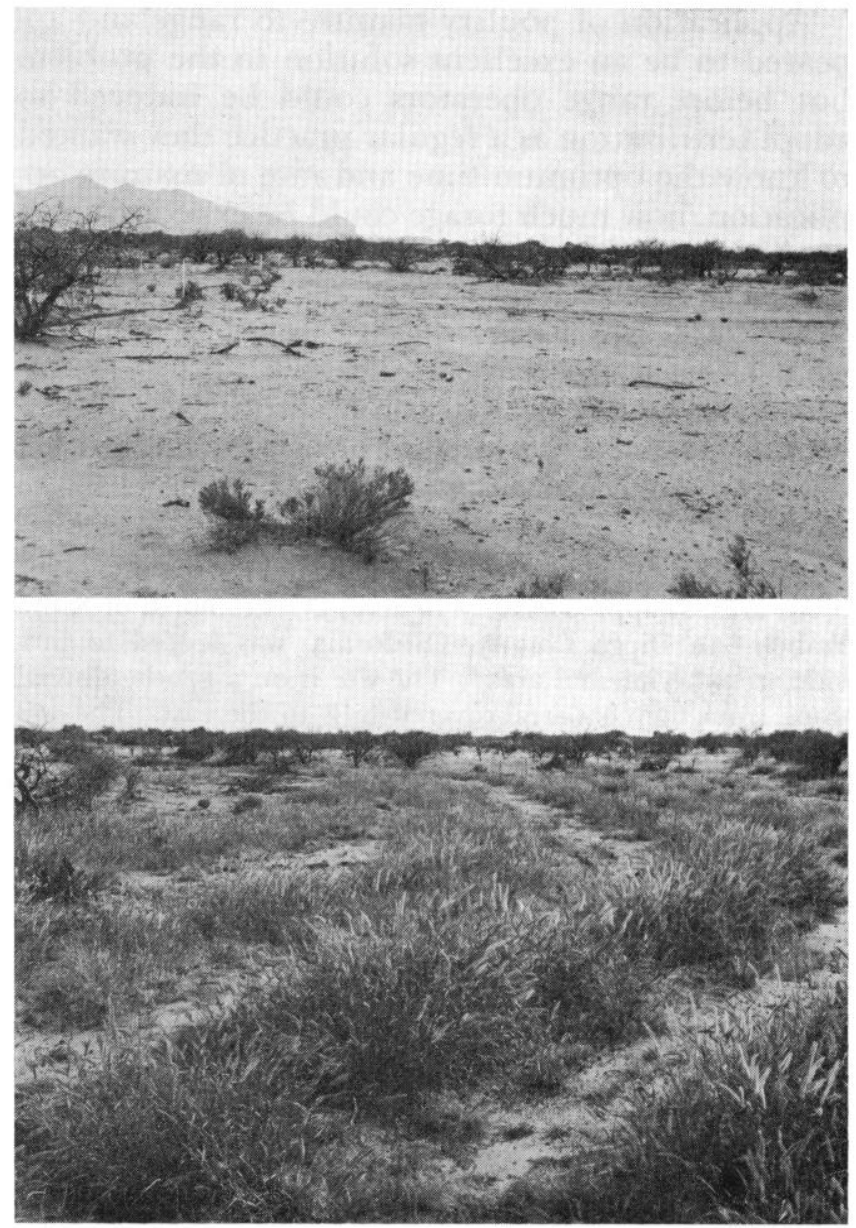

FIG, 2. Upper-Tubac clay loam severely eroded area before pitting. March 1964. Lower-Same area in 1967, showing buffelgrass in intermediate pits.

mained effective (Fig. 2) and were still effective, although partially filled, as of July 1969. The pits on the eroded clay loam have filled more than those on the loam and sandy loam soils.

Herbage production in 1967 averaged 1,189 lb/ acre for all soils and dates of planting on intermediate pits but only $230 \mathrm{lb} /$ acre on conventional pits. These differences were highly significant, but differences between soil and years of planting were not significant. Average production for the 4-year period was $2 \frac{1}{2}$ times as great on intermediate pits (690 lb/acre) as on conventional pits (253 lb/acre). The 4-year average production of native perennial grasses on adjacent mesquite-free range was 138 lb/acre. Mesquite-infested native range produced only $21 \mathrm{lb} /$ acre. Production figures for pitting assume complete coverage of the treated area (no space between rows of pits).

Moisture penetration in the basins and on the flats between basins differed significantly among
Table 3. Rainfall (inches) and moisture penetration (inches) in and adjacent to intermediate pits on the Santa Rita Experimental Range, 1963.

\begin{tabular}{|c|c|c|c|c|c|c|c|}
\hline & \multicolumn{6}{|c|}{ Period ending } \\
\hline & & $7 / 16$ & $7 / 27$ & $8 / 1$ & $8 / 8$ & $8 / 16$ & $8 / 25$ \\
\hline \multicolumn{2}{|c|}{ Rain during period } & 1.50 & .90 & 2.00 & .68 & .25 & .67 \\
\hline \multicolumn{8}{|c|}{ Moisture penetration: } \\
\hline \multirow[t]{2}{*}{ Sandy loan } & - Flat $^{1}$ & 5 & 9 & 22 & 10 & 17 & 22 \\
\hline & - Basin & 24 & 26 & 34 & 27 & 28 & 28 \\
\hline \multirow[t]{2}{*}{ Loam } & - Flat & 7 & 9 & 11 & 7 & 17 & 15 \\
\hline & - Basin & 15 & 15 & 27 & 27 & 27 & 23 \\
\hline \multirow[t]{2}{*}{ Clay loam } & - Flat & 2 & 8 & 15 & 5 & 5 & 6 \\
\hline & - Basin & 11 & 12 & 19 & 16 & 15 & 12 \\
\hline
\end{tabular}

${ }^{1}$ Penetration measured 2 to $3 \mathrm{ft}$ from pits.

soils, between the two locations, and among sampling dates (Table 3). Penetration in the basins averaged 28 inches on the sandy loam soil, 22 inches on the loam, and 14 inches on the clay loam; penetration averaged only half as deep on the flats as in the basins for each soil type.

\section{Conclusions}

These results indicate that constructing intermediate pits on semidesert ranges results in deep percolation of rainfall, and in more successful, longerlasting, and more productive stands of buffelgrass than can be obtained with conventional pits.

The results presented here constitute a progress report. Observations to determine the effective life of intermediate pits will continue. Additional trials are also under way with a modification of the intermediate pit to see if establishment and subsequent production of buffelgrass and other adapted forage species can be further improved. The economics of pitting and seeding have yet to be worked out, although increases in production attained to date make the procedure appear promising.

\section{Literature Cited}

Anderson, D., L. P. Hamilton, H. G. Reynolds, and R. R. Humphrey. 1957. Reseeding desert grassland ranges in southern Arizona. Univ. of Arizona Agr. Exp. Sta. Bull. 249:15-17.

Anderson, D., and A. R. Swanson. 1949. Machinery for seedbed preparation and seeding on southwestern ranges. J. Range Manage. 2:64-66.

AUstin, Morris E. 1965. Land resource regions and major land resource areas of the United States. U.S. Dep. of Agr. Handbook 296. 82 p.

Frost, K. R., And L. P. Hamilton. 1964. Mechanization of range reseeding. Prog. Agr. in Arizona 16(1):4-6. 